\title{
Dual-Source Dual-Energy Thin-Section CT Combined with Small Field of View Technique for Diagnosing Small Lymph Node in Thyroid Cancer
}

\section{Research}

Keywords:

Posted Date: October 28th, 2020

DOl: https://doi.org/10.21203/rs.3.rs-96230/v2

License: (c) (1) This work is licensed under a Creative Commons Attribution 4.0 International License.

Read Full License 


\section{Abstract}

The authors have requested that this preprint be withdrawn due to erroneous posting.

\section{Full Text}

The authors have withdrawn this preprint from Research Square. 